\title{
Linguistic, Pragmatic, and Stylistic Peculiarities of 2018 FIFA World Cup Representation in British Media-Discourse
}

\author{
Natalya N. Koshkarova \\ South Ural State University (National Research University) \\ 76 Lenin St., Chelyabinsk, 454080, Russia
}

\begin{abstract}
The purpose of the present research is to analyse linguistic, pragmatic, genre and stylistic peculiarities of the articles from British mass-media which cover the organization and the results of the 2018 World Cup. The importance of such analysis is determined by the necessity to investigate the public evaluation of the phenomenon under study. This will contribute to the understanding of mundane interpretations of sport in a particular culture and analyse the means of the country's image formation. Quality and tabloid newspapers were used as the basis for the analysis, with the aim of creating an integral picture of the world's attitude to the World Cup. The methods of discourse analysis and the analysis of the communicative situations let the author conclude that political discourse has an enormous influence on sport discourse. The politicization of sport discourse happens because of the discussion of topics from the conceptual sphere POLITICS, through the inclusion of controversial issues, on which Russia has not yet reached an understanding with the world community, into defamatory contexts. In the framework of sport discourse, the 'friend-foe' opposition becomes explicit, which is also characteristic of political discourse. In the British mass-media the materials with a positive illocutionary intention are mostly realized alongside with the foregrounding of politically charged issues and axiologically marked concepts. The analysis of publications in foreign mass-media is important for the purpose of understanding that ambitious sport projects help to ruin the stereotypes about Russia and create a positive image of the country on the world arena.
\end{abstract}

Keywords: FIFA World Cup, sport discourse, political discourse, mass-media discourse, axiogenic situation, the country's image

\section{For citation:}

Natalya N. Koshkarova (2019). Linguistic, Pragmatic, and Stylistic Peculiarities of 2018 FIFA World Cup Representation in British Media-Discourse. Russian Journal of Linguistics, 23 (3), 802-819. doi: 10.22363/2312-9182-2019-23-3-802-819. 


\title{
Лингвопрагматические и жанрово-стилистические особенности репрезентации чемпионата мира по футболу 2018 г. в британском медиадискурсе
}

\author{
Н.Н. Кошкарова \\ Южно-Уральский государственный университет \\ (национальный исследовательский университет) \\ 76, пр. Ленина, Челябинск, 454080, Россия
}

\begin{abstract}
Аннотация
Целью настоящего исследования является анализ лингвопрагматических и жанрово-стилистических особенностей публикаций в британских СМИ, освещающих проведение и итоги чемпионата мира по футболу 2018. Актуальность исследования обусловлена необходимостью лингвистического изучения общественной оценки анализируемого явления, что позволит составить представление об обыденном толковании спорта в определенной культуре с целью анализа способов и средств создания имиджа страны. В качестве эмпирического материала использовались как авторитетные печатные издания (The Times, The Guardian, The Daily Telegraph, The Independent), так и таблоиды (The Daily Mail, The Daily Mirror, The Sun) для создания более целостной картины отношения британского общества к прошедшему чемпионату. С помощью метода дискурсивного анализа, а также контекстуального изучения коммуникативных ситуаций автор приходит к выводу, что политический дискурс оказывает существенное влияние на спортивный дискурс. Политизация спортивного дискурса происходит в первую очередь за счет обсуждения тем из концептуальной сферы ПОЛИТИКА, через включение в диффамирующий контекст вопросов, по которым Россия еще не пришла к консенсусу с мировым сообществом. В рамках спортивного дискурса эксплицируется оппозиция «свои-чужие», характерная и для политического дискурса. Материалы с положительным иллокутивным намерением также присутствуют в британском медиадискурсе, но они по большей части реализуются наряду с актуализацией политически нагруженных вопросов и аксиологически маркированных концептов. Анализ публикаций в зарубежных СМИ важен с точки зрения понимания того, что крупные спортивные проекты оказывают неоценимую помощь в разрушении стереотипов о России и создании положительного имиджа страны на мировой арене.
\end{abstract}

Ключевые слова: чемпионат мира по футболу, политический дискурс, спортивный дискурс, масс-медийный дискурс, аксиогенная ситуаџия, имидж странь

\section{Для цитирования:}

Кошкарова Н.Н. Лингвопрагматические и жанрово-стилистические особенности репрезентации чемпионата мира по футболу 2018 г. в британском медиадискурсе // Russian Journal of Linguistics. 2019. T. 23. No 3. C. 802-819. doi: 10.22363/2312-9182-2019-23-3-802-819.

\section{1. Введение}

Чемпионат мира по футболу FIFA 2018 стал для России поистине знаковым событием с точки зрения различных аспектов функционирования российского общества и формирования имиджа страны на мировой арене. Спортивный турнир послужил мощным импульсом для развития городов, принимавших матчи мундиаля. Стране предстоит оценить экономический эффект от проведения чемпионата. Не вызывает сомнения тот факт, что мундиаль - это дополнительный инструмент для развития спортивного движения в России. Однако мы глубоко 
убеждены в том, что помимо стимулирования социально-экономического развития страны в целом и ее отдельных территорий, такие крупные спортивные соревнования решают и еще одну важную задачу: «повышение авторитета страны в глазах мирового сообщества» (Давыдова, Дулина, Икингрин, Коричко 2018: 69).

15 июля 2018 г. на гала-концерте в преддверии финала чемпионата мира по футболу президент России В.В. Путин сказал: «Мы рады, что наши гости все видели своими глазами, что рухнули мифы и предубеждения» (Путин 2018). Действительно, прошедший чемпионат стал действенным инструментом разрушения стереотипов и предрассудков, созданных западными средствами массовой информации до начала проведения спортивного мероприятия. Не стоит отрицать тот факт, что большинство материалов, опубликованных западными СМИ в ходе подготовки чемпионата мира, носили клеветнический, фейковый и диффамационный характер.

Такие публикации ${ }^{1}$ являются примером ситуации, когда спортивный дискурс испытывает на себе влияние политического дискурса. Тема политизации спортивного дискурса затрагивается в большом количестве публикаций (Иванова 2014; Мартыненко 2014; Новиков 2015; Русакова, Корнеева 2016; Филонов, Юдина 2018; Shippi 2012; Zirin 2013). Н.В. Новиков одной из причин такой ситуации видит в «соревновательном духе», в актуализации оппозиции свои/чужие, которая характеризует как политическую, так и спортивную жизнь (Новиков 2015: 207). Такая позиция созвучна утверждению Е.Г. Малышевой о том, что «концепт „Спорт“ является одной из универсальных идеологем русской идеологической картины мира» (Малышева 2009: 337). По справедливому замечанию автора, «универсальность идеологемы „Спорт“ ... заключается в том, что ее содержание одинаково понимается и оценивается политиками и государственными деятелями разной политической ориентации, и она используется в политическом дискурсе сторонников самых разных политических взглядов (Там же: 336).

Вполне правомерно утверждать, что спорт и спортивные состязания как неотъемлемая часть социальной жизни человека принадлежат к числу аксиологически маркированных событий, которые «осмысливаются в виде концептов квантов переживаемого знания - и объективируются в семантике слов и фразеологизмов, в высказываниях, определенных сюжетах и жанрах речи» (Карасик 2014: 65). Спорт, футбол в частности, детерминирован ценностными установками и приоритетами участников не только спортивного, но и политического (в большей степени) дискурса, так как состояние современного спортивного мира говорит о том, что концепция «спорт вне политики» в настоящее время теряет свою актуальность (Мартыненко 2014). Лингвопрагматические характеристики материалов,

${ }^{1}$ Backers shun 'toxic' FIFA brand, leaving Russia 2018 World Cup facing financial crisis. The Daily Mirror. May 1, 2017.

FIFA promise to investigate doping in football: 'We WILL test suspect Russia samples before start of the World Cup. The Daily Mail. December 23, 2017.

Mascot fears at 2018 World Cup as McDonald's my not take kids to Russia over safety risks. The Mail Online. March 8, 2018. 
освещающих спортивные события в средствах массовой информации, представляют интерес для изучения с лингвистической точки зрения, так как позволяют выявить все грани общественной оценки анализируемого явления, составить представление об обыденном толковании спорта в той или иной культуре, подвергнуть анализу способы и средства создания имиджа страны. Таким образом, целью настоящего исследования является анализ публикаций в британских средствах массовой информации, освещающих проведение чемпионата мира по футболу в России.

\section{2. Материал исследования}

Материалом для исследования послужили статьи в британских СМИ, опубликованные в период проведения чемпионата мира по футболу, то есть с 14 июня по 15 июля 2018 г. (плюс минус один-два дня). В качестве источников эмпирической базы использовались следующие издания: The Daily Mail, The Daily Mirror, The Sun, The Times, The Guardian, The Daily Telegraph, The Independent. Мы намеренно исключили из временного контекста публикации дискредитирующего характера, вышедшие в свет в период подготовки мундиаля, так как «туманная атака» на чемпионат мира неоднократно становилась объектом научного интереса ученых (Милованова, Свинкина 2018; Саражакова 2018), в том числе и в наших публикациях (Кошкарова 2018). Всего было проанализировано 45 публикаций, ключевым словосочетанием для поиска на страницах интернет-версий указанных газет была номинация 2018 FIFA World Cup.

Как видно из приведенного списка, в него вошли как авторитетные печатные издания (The Times, The Guardian, The Daily Telegraph, The Independent), так и таблоиды (The Daily Mail, The Daily Mirror, The Sun), что дает возможность создать более целостную картину отношения британского общества к прошедшему чемпионату. Гипотеза исследования заключается в том, что жанровая, тематико-стилистическая и лингвопрагматическая специфика указанных изданий будет являться вариативной реализацией инвариантной сюжетной модели формирования и реализации медиастратегии освещения спортивного события в британских СМИ. Дискурсивное пространство указанных СМИ характеризуется изоморфизмом, который преломляется в зависимости от редакционной политики конкретного издания.

Вопрос о роли средств массовой информации в формировании общественного мнения обсуждается в рамках многих научных направлений: политологии (Обидов 2017; Horniak 2016), социологии (Бабанов, Гришина 2018; Молодов 2016; Mehraj, Bhat, Mehraj 2014), философии (Прилукова 2013), журналистики (Суходолов 2014), лингвистики (Озюменко 2017; Солопова, Чудинов 2018; Пушкарева 2017, Larina et al. 2019, Thongprayoon, Hill 1996 и многие другие). Средства массовой информации, будучи «основными «поставщиками» коллективного знания, или посредниками в его распространении» (Володина 2015: 20), не только отражают действительность, но и зачастую формируют и конструируют новую реальность в соответствии с аксиологическими установками конкретного 
издания и (или) представляющего его журналиста. В последнее время зависимость идеологических пресуппозиций и установок акторов дискурса стала активно проявляться в таком виде институционального общения, как спортивный дискурс. Спортивный дискурс все чаще испытывает на себе влияние этнокультурных стереотипов и национальных особенностей коммуникантов. Взаимосвязь спортивного дискурса и базовых политических и идеологических ценностей отражена в определении первого, данного Е.Г. Малышевой: «спортивный дискурс - это особый тип институционального дискурса», в текстах которого «находят отражение многоаспектные проявления деятельности человека в спортивной сфере, в том числе универсальные и национально специфические представления о спорте и его составляющих как о базовых культурологических и идеологических ценностях» (Малышева 2017: 27).

Таким образом, выбор в качестве материала для исследования британских газет различного направления представляется оправданным, что является важным с точки зрения анализа роли СМИ в отражении спорта как социальной и дискурсивной практики.

\section{3. Методы исследования}

Выбор материала для исследования определяет совокупность методов, применяемых для анализа эмпирической базы: с целью изучения текстов британских СМИ в качестве ведущего использовался метод дискурсивного анализа, применение которого сопровождалось контекстуальным изучением коммуникативных ситуаций. Дискурсивный анализ масс-медиа является в настоящее время достаточно востребованным методом исследования, так как он позволяет «описать и понять процессы создания, обмена и дифференциации смыслов в пространстве массовой коммуникации (например, что изображается в СМИ как нормальное, допустимое, приемлемое, а что - нет, и какими контекстуальными связями это обусловлено), иерархизации репрезентаций (например, как и почему маркируются те или иные образы как более или менее привлекательные или как и в связи с чем определяется важность события), легитимации определенного опыта и практик (какие действия одобряются и как это осуществляется дискурсивно)» (Кожемякин 2010: 17-18). Как известно, разновидностью дискурс-анализа является столь востребованный и широко применяемый в настоящее время критический дискурс-анализ, «который включает понятие власть и анализирует то, как власть оперирует языком» (Понтон, Ларина 2016: 9). Такой подход релевантен для целей нашего исследования, так как на примере анализа репрезентации спортивного дискурса в текстах СМИ можно проследить взаимосвязь между дискурсом как социальной практикой и спортом как социальным и культурным явлением, детерминированным политическими условиями и обстоятельствами. Контекстуальный анализ выбранного материала «включает рассмотрение всех экстралингвистических факторов: времени, места, сферы деятельности, участников дискурса, их социальных ролей, характера их взаимоотношений и когнитивных характеристик участников дискурса» (Шапочкин 2013: 107). 


\section{4. Результаты исследования}

Чемпионат мира по футболу стал не только спортивным, но и геополитическим событием, интерес к которому был прикован с момента его подготовки. Как уже отмечалось выше, в подготовительный период британские СМИ использовали большой арсенал речевых средств для воздействия на целевую аудиторию в своих публикациях дискредитирующего характера: материалы касались проблемы допингового скандала ${ }^{2}$, отстрела бродячих собак на улицах российских городов ${ }^{3}$ и других тем, непосредственным образом не связанных с предстоящим спортивным событием. Прагматический потенциал таких публикаций можно определить как построение параллельной реальности, где Россию представляют «аутсайдером, постоянно увязающим в коррупции и сталкивающимся с прочими деструктивными процессами, но при этом стремящимся во что бы то ни стало попасть на мировую авансцену» (Воинов 2015: 176).

Несмотря на создание достаточно позитивного имиджа России в материалах, вышедших в свет в период проведения мундиаля, ряд публикаций носит диффамационный характер. Так, 15 июня 2018 г. в газете The Daily Mail была опубликована статья под заголовком Welcome to Volgograd ${ }^{4}$ :

When England arrive to play Tunisia they will discover the heartbeat of Vladimir Putin's nationalism - and the poorest host city - Добро пожаловать в Волгоград: когда англичане приедут, чтобы сразиться с Тунисом, они окажутся в центре начионализма Путина и самом бедном городе, принимающим чемпионат.

Негативный прагматический потенциал содержится уже в самом заголовке статьи: семантика номинации Vladimir Putin's nationalism созвучна риторике обвинений президента России в монополии на русский национализм и девальвацию этого понятия, которое не раз звучало со стороны западных партнеров (см., например, Joffe 2016). Лексема the poorest, негативный оценочный компонент которой усиливается за счет превосходной степени прилагательного, выражает соответствующую оценку в гипертрофированной и гиперболизированной форме и способствует созданию желаемого перлокутивного эффекта.

Негативный оценочный компонент анализируемого материала далее контекстуально поддержан за счет противопоставления как композиционно-стилистического приема организации текста:

But many here point to the contrasting economic fortunes of the victorious and defeated cities. 'We bear no comparison with Berlin,' says Aleksandr, an accountant. Многие здесь обращают внимание на диаметрально противоположное экономическое состояние городов-победителей и побежденных городов. 'Мы не выдерживаем никакого сравнения с Берлином', - говорит бухгалтер Александр.

2 FIFA promise to investigate doping in football: 'We WILL test suspect Russia samples before start of the World Cup. The Daily Mail. December 23, 2017.

${ }^{3}$ Putin 'to send 'canine death squads' out to slaughter stray dogs ahead of this year's World Cup. The Daily Mail. January 22, 2018.

${ }^{4}$ Welcome to Volgograd. The Daily Mail. June 15, 2018. 
Другим аргументом в пользу того, что спортивный дискурс все больше тяготеет к политическому дискурсу, является использование «оценочно нагруженных прецедентных имен» (Иванова 2014: 101), когда апелляция к аксиогенно детерминированной системе ассоциаций выполняет не информативную, а манипулятивную и интерпретативную функцию:

Even the memorials to the Battle of Stalingrad, which are everywhere, seem to root this place in the 1940s, idealising war without finding a modern way to articulate its futility. - Кажется, что памятники Сталинградской битве, которые здесь повсюду, оставили этот город в сороковых годах, идеализируя войну и не пытаясь найти современные способы объяснить ее бессмысленный характер.

Таким образом, политизация спортивного дискурса проявляется в активном использовании прецедентных имен (точнее, прецедентных событий), когда «автор развивает и детализирует высказанные ранее идеи, полемизирует с ними, дает свою интерпретацию фактов, подчеркивает собственную позицию на фоне обширного дискурса» (Нахимова 2014: 173). Так, в анализируемом материале при обсуждении животрепещущей темы безопасности болельщиков во время матчей спортивного турнира автор ссылается на жесткое столкновение, случившееся после матча группового этапа между Россией и Англией в Марселе летом 2016 г.:

Some locals do fear being caught up in the kind of fights between Russians and

English which occurred in Marseille two summers ago. - Некоторые местные жители опасаются повторения беспорядков в Марселе два года назад.

Русофобская истерия, созданная в британских СМИ, не помешала английским болельщикам приехать в Россию и насладиться игрой своей сборной, о чем сообщает та же газета The Daily Mail в статье, опубликованной 16 июня 2018 г. под заголовком England fans arrive in Volgograd ahead of first World Cup match ${ }^{5}$ - - Английские болельщики приезжают в Волгоград в преддверии первого матча чемпионата мира. Создание единого дискурсивного пространства между указанным материалом и статьей, проанализированной выше, достигается за счет упоминания о беспорядках в Марселе, которые могли стать препятствием для поездки английских болельщиков на мундиаль в России:

Mr. Clarke said he was in Marseille during the European Championships in 2016, and was concerned there may be a repeat of the violence which marred the tournament. Господин Кларк сообщил, что он был в Марселе во время чемпионата Европь в 2016 г. и опасался повторения беспорядков, которые омрачили тогда этот турнир.

Но реальность превзошла все ожидания, и в статье приводятся лишь восхищенные отзывы английских болельщиков:

I was a bit worried about what it was going to be like, but soon realised it's an amazing place. It's so clean, so friendly and everyone is really polite. Everyone's coming up to me asking me where I'm from. I've seen about 10 England fans, there're more Russians in England shirts. Yesterday I wasn't wearing my England shirt and no one came to me - today everyone is coming to me and welcoming me to Russia. - В начале я опасался того, что ждет меня впереди, но вскоре понял, что это отличное место. Здесь все так иисто,

5 England fans arrive in Volgograd ahead of first World Cup match. The Daily Mail. June 16, 2018. 
все настолько дружелюбны и вежливы. Многие подходят ко мне и спрашивают, откуда я приехал. Я уже встретил около десяти фанатов из Англии, а многие русские одеть в английские футболки. Вчера я не надел английскую футболку, и никто не подошел ко мне, а сегодня многие хотят познакомиться со мной, и они рады видеть меня в России.

В статье под заголовком The World Cup helped Russia put on its best face and the world smiled back - Чемпионат мира помог России показать себя с лучшей сторонь, а мир ульбннлся в ответ, опубликованной в газете The Independent 14 июля 2018 г., автор использует тактику призыва с целью «выполнить некоторое действие, которое является частью общественной или политической деятельности и может быть значимо для широкого круга лиц» (Чернышева 2016: 153):

Forget everything you ever read or thought about Russia - this is absolutely brilliant! It's such a shame so many people were put off. — Забудьте все, что вы раньие читали или думали о России - страна совершенно великолепна. Жаль, что многие были лишены этой возможности.

Восхищение автора по поводу увиденного во время чемпионата мира актуализируется посредством прилагательных с положительной оценкой hospitable, organised, modern:

To our collective joy, edification and more than slight embarrassment, the Russia we found was hospitable, organised, modern, bending over backwards to help us - and ready to party. - К нашей всеобщей радости и к стылду Россия оказалась гостеприимной, организованной, современной, готовой помочь и умеющей веселиться страной. Пребывание здесь послужит нам хорочим уроком.

В процессе межкультурного диалога и реализации концептуальной оппозиции политического дискурса «свои-чужие» немаловажную роль играет концепт «еда», который семантизирован в тексте статьи через трофонимы - языковые единицы, обозначающие названия блюд:

Even the food, sometimes ridiculed as stodgy and bland, was getting a thumbs-up, especially the ubiquitous Georgian cordon bleu, smoky Armenian cafes, and surprisingly affordable Siberian caviar. - Даже еда, которую поначалу высмеивали как однообразную и безвкусную, оказалась достойной похвалы, особенно грузинский коньяк, закоптелье армянские кафе и даже черная икра по удивительно доступной иене.

В целом необходимо отметить, что глюттонический дискурс в его функционально-стилистических и коммуникативно-прагматических аспектах занимает важное место в публикациях британских СМИ о прошедшем чемпионате мира. Так, одной из активно обсуждаемых тем стала проблема нехватки пива в жаркие летние дни во время проведения мундиаля:

BEER BARREN. England World Cup fans face Russia beer shortage as boozy supporters drink parts of Moscow dry ${ }^{7}$ - - Нехватка пива. Английские болельщики столкнулись с нехваткой пива, так как охочие до выпивки осушили бары Москвы.

${ }^{6}$ The World Cup helped Russia put on its best face - and the world smiled back. The Independent. July 14, 2018.

7 BEER BARREN. England World Cup fans face Russia beer shortage as boozy supporters drink parts of Moscow dry. The Sun. June 20, 2018. 
High and dry! Panic for football fans as Moscow faces running out of BEER during the World Cup - Paдостные и обезвоженнье! Футбольные болельщики в панике из-за нехватки пива в Москве во время чемпионата мира.

Как видно из приведенных контекстов, мишенью для дискредитации стали факты из российской действительности, которые имеют лишь косвенное отношение к анализируемому спортивному мероприятию. В большинстве публикаций в диффамирующий контекст вплетены и политические вопросы, по которым Россия не всегда может найти общий язык со странами мирового сообщества:

Of course, there will be a reality check after the love-in with Russia. It does still snow here in other seasons, no amount of fan fun can hide some serious political problems, and critics will say president Vladimir Putin has exploited the tournament to clean an increasingly pariah image abroad ${ }^{9}$. - Конечно, после этой влюбленности в Россию мы снова вернемся в реальность. Здесь все еще идет снег в другие времена года и никакая любовь фанатов не может скрыть политические проблемы. Критики утверждают, что Владимир Путин использовал чемпионат с иелью улучшения имиджа России как страны-изгоя за рубежом.

Mr. Putin, no doubt, hopes the world can forget about politics for a month, and instead envelop itself in the enigmatic (mythical) charm of the Russian soul. The reality is likely to prove different ${ }^{10}$. - Безусловно, господин Путин надеется, что мир на месяи забудет о политике и окажется во власти загадочного и мифического очарования русской души, но реальность, вероятно, докажет обратное.

Несмотря на большое количество позитивных высказываний в адрес России и прошедшего чемпионата мира, негативный образ нашей страны активно создается в анализируемых публикациях, а главным аргументом при этом является дело Скрипаля:

But critics fear the World Cup will legitimize Putin's autocratic policies at home and Russia's actions abroad, from alleged meddling in the U.S. presidential election to annexing the Crimean Peninsula from Ukraine and a suspected nerve agent attack in Britain. Moscow vehemently denies any interference in the American vote or involvement in the attack against a former Russian spy in Salisbury ${ }^{11}$. - Но критики опасаются, что чемпионат мира укрепит авторитарную политику Путина внутри страны и действия России на международной арене: вмемательство в президентскую кампанию в США, аннексию Крымского полуострова и подозрение в использовании нервнопаралитического вещества в Великобритании. Москва категорически отрицает свое вмешательство в американские выборы или причастность к покушению на бывшего российского разведчка в Солсбери.

${ }^{8}$ High and dry! Panic for football fans as Moscow faces running out of BEER during the World Cup. The Sun. June 20, 2018.

9 The World Cup helped Russia put on its best face - and the world smiled back. The Independent. July 14, 2018.

${ }^{10}$ Putin's Kremlin is hoping to use World Cup to bring Russia out of isolation. The Independent. June 11. 2018.

${ }^{11}$ Russian hopes, fears tied up in Putin's showcase World Cup. The Daily Mail. June 14. 2018. 
Как было отмечено выше, спортивный дискурс становится все более и более политизированным, на что указывают и британские СМИ (приведенный контекст взят из лида, для которого характерно опущение глагола-связки):

Rarely has a World Cup been more politicised, but Russia optimistic the tournament will mark a turnaround in its international fortunes ${ }^{12}$. - Редко какой чемпионат мира был настолько политизированным, но Россия надеется, что турнир станет поворотным пунктом в улучшении международного имиджа страны.

Арсенал речевых средств, используемых для политизации спортивного дискурса в анализируемых публикациях достаточно широк: от привлечения фактологического материала в манипулятивных целях до сравнения политики, проводимой Россией, с образом официального талисмана ЧМ. Напомним, что им стал антропоморфный волк Забивака, когда человеческие свойства были перенесены на представителя животного мира. В каждой культуре существует национально детерминированные стереотипы об образах животных: так, в славянской традиции волк - это предок домашней собаки и во многом близок к ней по повадкам. В западной традиции волк ассоциируется со злом и даже смертью (Bukowick 2004: 66). Этнокультурные различия в символике животных положены в основу противопоставления образа милого волка и «реальности внешней политики России»:

The reality of Russian foreign policy is in such sharp, indeed grotesque, contrast to the civilised, cuddly image symbolised in Zabivaka, the friendly wolf adopted as the mascot of this championship. There is no such thing, in the natural world nor in international diplomacy, as a friendly wolf. Perhaps that is Mr. Putin's idea of satire, a nice twist on the old line of "a wolf in sheep's clothing"13. - Реальность внешней политики России находится в резком и абсурдном контрасте с образом милого и дружелюбного талисмана Забиваки. Ни в природном мире, ни в международной дипломатии не существует дружелюбного волка. Возможно, это попьтка Путина проявить юмор и иронию, вариант пословиць «волк в овечьей шкуре».

Другой активно обсуждаемой темой в медиадискурсе британских СМИ во время проведения чемпионата стала проблем ЛГБТ-сообществ в России, что, по мнению Д.Е. Воинова, объясняется популяризацией «ценностей «fair play» («честной игры») и «уважения» (подразумевается взаимоуважение между спортсменами, зрителями и соблюдение правил соревнований) в рамках чемпионатов FIFA» (Воинов 2015: 165). Так, 16 июня 2018 г. газета The Independent сообщила о том, что в Санкт-Петербурге запущен проект Cup for People, в рамках которого активисты и правозащитники объединились для того, чтобы привлечь внимание международных организаций и журналистов к правам ЛГБТ-сообщества, экологическим проблемам и другим социальным вопросам.

12 Putin's Kremlin is hoping to use World Cup to bring Russia out of isolation. The Independent. June 11. 2018.

${ }^{13}$ Usually boycotting a world sporting event would seem extreme, but this is Putin's Russia we're talking about. The Independent. June 14. 2018. 
Газета The Sun в своей статье от 28 июня 2018 с одноименным названием задает следующие вопросы: Противозаконен ли гомосексуализм в России? Какие законы, ограничивающие права ЛГБТ-сообщества, подписал Владимир Путин? Каково отношение к ЛГБТ-сообществу в России? Одним из синтаксических средств, использованных у казанном материале, являются уступительно-противительные придаточные предложения с союзами while, although:

While it's not against the law to be in a gay relationship in Russia, same sex marriages are illegal. - Хотя находиться в однопольх отношениях в России не противоречит закону, но однополье браки являются незаконными.

Although sexual activity between gay people was decriminalised in 1993, homosexual couples are not eligible for the legal protections offered to heterosexuals in Russia. Хотя сексуальные отношения между геями были декриминализованы в 1993 году, гомосексуальные пары не имеют в России никакой правовой защиты ${ }^{14}$.

Использование подобного синтаксического приема дает возможность автору указать на отсутствие достаточной социальной поддержки ЛГБТ-сообщества в России, несмотря на наличие изменений в отношении прав ЛГБТ-граждан.

В начале мундиаля уже упомянутая газета The Independent заявляла о том, что Россия печально известна неблагоприятной статистикой по вопросам защиты прав ЛГБТ-сообщества; о том, что ЛГБТ-комьюнити в России подвергается насилию, преследованию, нарушению прав и дискриминации. В такой ситуации, утверждает издание The Independent в статье от 17 июня 2018 г., России следовало отказать в проведении столь престижного соревнования:

Russia should never have been granted the right to host this prestigious tournament, given the country's appalling human rights record. - России следовало бы отказать в праве принимать у себя этот престижный турнир, учитывая ужасную ситуацию с правами человека в стране ${ }^{15}$.

Негативный прагматический потенциал данного высказывания усиливается за счет использования в тексте статьи лексических единиц с эмоционально-оценочным компонентом: homophobic (гомофобный), appalling (устрашающий), unconstitutional (неконституционньій), roguе (репрессии), purge (моченник).

Именно царящая в России гомофобная риторика и насилие против ЛГБТсообщества, по мнению газеты The Telegraph (18 июня 2018 г.), постоянно находятся в центре внимания мировой прессы: Violence against gays and homophobic rhetoric in Russia regularly make global headlines ${ }^{16}$.

Столь критическое и негативное настроение в анализируемых материалах сменилось с течением времени, и газета The Daily Mail в материале от 29 июня 2018 г. сообщает о том, что проведение чемпионата мира сделало Россию более

${ }^{14}$ Is homosexuality illegal in Russia, what laws has Vladimir Putin enacted and how are LGBT people treated in the country? The Sun. June 28, 2018.

${ }_{15}$ We spoke to activist Peter Tatchell about his one-man protest and detainment. The Independent. June 17, 2018.

${ }^{16}$ World Cup 2018: 'Safe space' for LGBT football fans in Russia forced to move after 'political attack'. The Telegraph. June 18, 2018. 
'gay-friendly'. Хотя в материале от 25 июня 2018 г. журналисты этой газеты высказывали опасение по поводу того, что такие послабления в отношении ЛГБТ-сообщества прекратятся с завершением чемпионата.

Однако, как мы уже отмечали выше, материалы с положительной риторикой доминируют в медиапространстве британских СМИ, что, на наш взгляд, объясняется умелым использованием Россией шансов «на капитализацию национального имиджа с помощью мундиаля» (Воинов 2015: 177). В рамках национальной медиастратегии, реализуемой обеими сторонами (Россия vs. Запад), спорт превращается в эффективное оружие информационно-психологической войны. Победу в такой войне одержит тот, кто сможет умело воспользоваться политическими и медийными итогами крупных спортивных мероприятий.

Газета The Daily Mail в начале проведения мундиаля (17 июня 2018 г.) писала:

He (Russian President Vladimir Putin. - N.K.) wants the world to walk away from this tournament in awe, not in fear ${ }^{17}$. - Президент России Владимир Путин хочет, чтобь мир уехал с турнира в восхищении, а не страхе.

В той же газете в материале от 14 июня 2018 г. находим восторженные отклики по поводу усилий России провести чемпионат на высоком уровне:

Russian President Vladimir Putin claims soccer and politics have nothing to do with each other, yet the World Cup he kicked off Thursday is about much more than sports. It's about proving to the world that Russia is a global power broker and not an outcast, that it's an open, confident and generous nation - and not an isolated, repressive place hobbled by sanctions ${ }^{18}$. - Президент России Владимир Путин заявляет, что футбол и политика не связаны между собой, но чемпионат мира, который он открыл в четверг, имеет дело не только со спортом. Чемпионат помогает доказать, что Россия это влиятельный субъект на международной арене, а не изгой, что Россия - это открытая, уверенная в себе и щуедрая нация, а не изолированная и загнанная в угол санкциями страна.

Чемпионат мира стал эффективным инструментом разрушения стереотипов о России, которые могут рассматриваться как социальные конструкты, через призму идеологии и ее реализации в конкретном типе дискурса (Tomi 2001):

The rank-and-file Russian people were magnificent hosts. They were generous, welcoming, smiling wreckers of lazy Western stereotypes. Their nation is as rich in history, culture and beauty as their oligarchs are in cash ${ }^{19}$. - Обычные русские люди оказались великолепныли хозяевами. Своим гостеприимством, щедростью, ульббчивостью они разрушили нелепье стереотипы, созданные на Западе. Русская нация настолько же богата историей, культурой и красотой, насколько богаты ее олигархи.

Как видно из приведенного фрагмента, хвалебные отзывы о прошедшем чемпионате реализуются наряду с аксиологически маркированным концептом ОЛИГАРХИЯ. Более того, положительная коннотация восторженных эмоций

17 Russia's headache: Keeping it safe, keeping it fun. The Dally Mail. June 17, 2018.

18 Russian hopes, fears tied up in Putin's showcase World Cup. The Daily Mail. June 14. 2018.

19 What a party. World Cup 2018 had everything - even an England team we could be proud of. The Sun. July 16, 2018. 
от чемпионата нивелируется и (или) даже сводится на нет за счет критики в адрес режима В. Путина:

Beyond all the FIFA corruption and the evils of Vladimir Putin's regime, and the myriad of reasons why they should never have actually staged it, Russia put on an extravagant party ${ }^{20}$. - Несмотря на коррупиионный скандал в ФИФА и все ужсасы путинского режсим, несмотря на миллионы причин, почему России не следовало проводить чемпионат, Россия устроила грандиозный праздник.

Анализ речевого материала показывает, что трансляция положительных отзывов о прошедшем чемпионате происходит через актуализацию политически нагруженных вопросов:

Putin's Russia is responsible for the Salisbury poisoning with novichok - but the World Cup belongs to football fans everywhere. It is Putin's Russia that has been responsible for downing MH17; for cyberwarfare; for fanning the flames of conflict in Ukraine and for poisoning British citizens in Wiltshire ${ }^{21}$ - Россия Путина ответственна за отравление новичком в Солсбери, но чемпионат мира принадлежит футбольным болельщикам по всему миру. Именно Россия Путина ответственна за катастрофу Боинга 777, за кибервойну, за обострение ситуации на Украине и отравление британских граждан в Уилтишире.

Но при всей политической ангажированности таких публикаций радует то, что их авторы осознают неоспоримый факт:

It was certainly Putin's Russia that won the right to host the World Cup. But this World Cup does not belong to the Kremlin. It belongs to football fans everywhere in the world $^{22}$. - Именно Россия Путина вылграла право принимать чемпионат мира. Но чемпионат мира не принадлежит Кремлю. Он принадлежит болельщикам по всему миру.

Как видно из приведенного лингвопрагматического анализа текстов британских СМИ, посвященных итогам чемпионата мира по футболу 2018, их авторы используют широкий арсенал средств для воздействия на целевую аудиторию: прецедентные имена, актуализация насущных вопросов современной политики, реализация концептуальной оппозиции политического дискурса «свои-чужие». Последнее обстоятельство дает нам основание прийти к выводу о том, что спортивный дискурс в настоящее время испытывает на себе значительное влияние современных общественно-политических факторов и условий. Наиболее ярко проявление идеологических установок эксплицировано в спортивном медиадискурсе, основная цель которого заключается не только в информировании, но и интерпретации при освещении спортивных событий.

${ }^{20}$ What a party. World Cup 2018 had everything - even an England team we could be proud of. The Sun. July 16, 2018/

${ }^{21}$ The World Cup 'does not belong to Vladimir Putin' and an England boycott would only cheat fans. The Sun. June 14, 2018.

${ }^{22}$ The World Cup 'does not belong to Vladimir Putin' and an England boycott would only cheat fans. The Sun. June 14, 2018. 


\section{5. Заключение}

Таким образом, анализ британских публикаций, вышедших в свет во время проведения чемпионата мира по футболу 2018, показывает, что риторика материалов, опубликованных в качественных изданиях и в таблоидах, кардинально не отличается. Однако лингвистический анализ публикаций позволяет сделать вывод о влиянии политического дискурса на спортивный дискурс. Политизация спортивного дискурса происходит в первую очередь за счет обсуждения тем из концептуальной сферы ПОЛИТИКА, через включение в диффамирующий контекст вопросов, по которым Россия еще не пришла к консенсусу с мировым сообществом. В рамках спортивного дискурса эксплицируется оппозиция «своичужие», характерная для политического дискурса. Материалы с положительной риторикой также присутствуют в медиадискурсе британских СМИ, но они по большей части реализуются наряду с актуализацией политически нагруженных вопросов и аксиологически маркированных концептов.

В проанализированных текстах британских СМИ используются следующие речевые и языковые средства: лексические единицы с негативном и эмоциональнооценочным компонентом, противопоставление как композиционно-стилистический прием, отсылка к прецедентным именам, сравнение, апелляция к идеологически окрашенным концептам.

Анализ публикаций в зарубежных СМИ важен с точки зрения понимания того, что крупные спортивные проекты оказывают неоценимую помощь в разрушении стереотипов о России и создании положительного имиджа страны на мировой арене. В этой связи важным является сохранение и преумножение имиджевого капитала, накопленного во время мундиаля, его использование с целью укрепления положения страны на мировой арене и недопущения информационных атак на Россию.

(C) Н.Н. Кошкарова, 2019 cc) commons

https://creativecommons.org/licenses/by/4.0/

\section{Список литературы / References}

Бабанов И.В., Гришина Е.А. Современный спорт - проблемы и противоречия // Социологические исследования. 2018. № 6. С. 116-124. [Babanov, I.V., Grishina, E.A. (2018). Sovremennyi sport — problemy i protivorechiya. In Sotsiologicheskie issledovaniya, 6, 116-124. (In Russ.)]

Воинов Д.Е. «Мягкая сила» игр «Сочи-2014» и зарубежные медиа: анализ политико-информационного фона российской Олимпиады // Вестн. Моск. ун-та. Сер. 25: Международные отношения и мировая политика. 2015. № 2. C. 155-181. [Voinov, D.E. (2015). «Myagkaya sila» igr «Sochi-2014» i zarubezhnye media: analiz politico-informatsionnogo fona rossiiskoi olimpiady. Moscow University Journal of World Politics, 2, 155-181. (In Russ.)] 
Володина М.Н. Социальная и информационно-языковая роль текстов массовой коммуникации // Жанры и типы текста в научном и медийном дискурсе. 2015. C. 20-26. [Volodina, M.N. (2015). Sotsialnaya i informatsionnoyazykovaya rol tekstov massovoi kommunikatsii. In Zhanry i tipy teksta v nauchnom i mediinom diskurse, 20-26. (In Russ.)]

Давыдова С.А., Дулина Н.В., Икингрин Е.Н., Коричко Ю.В. Чемпионат мира по футболу FIFA-2018: ожидания и мнения студентов России // Теория и практика физической культуры. 2018. № 6. C. 68-72. [Davydova, S.A., Dulina, N.V., Ikingrin, E.N., Korichko, Yu.V. Chempionat mira po futbolu FIFA - 2018: ozhidaniya i mneniya studentov Rossii (2018). Teoriya i praktika fizicheskoi kultury, 6, 68-72. (In Russ.)]

Иванова С.В. Политика на спортивных полях (заметки на полях спортивных материалов чемпионата мира-2014 по футболу) // Политическая коммуникация: перспективы развития научного направления. УрГПУ. 2014. С. 95-102. [Ivanova, S.V. (2014). Politika na sportivnykh polyakh (zametki na polyakh sportivnykh materialov chempionata mira-2014 po futbolu. In Politicheskaya kommunikatsiya: perspektivy razvitiya nauchnogo napravleniya, 95-102. (In Russ.)]

Карасик В.И. Аксиогенная ситуация как единица ценностной картины мира // Политическая лингвистика. 2014. № 1 (47). С. 65-75. [Karasik, V.I. (2014). Aksiogennaya situatsiya kak edinitsa tsennostnoi kartiny mira. Political Linguistics Journal, 1 (47), 65-75. (In Russ.)]

Кожемякин Е.А. Массовая коммуникация и медиадискурс: к методологии исследования // Научные ведомости. Серия Гуманитарные науки. 2010. № 12 (83). Вып. 6. С. 13-21. [Kozhemyakin, E.A. (2010). Massovaya kommunikatsiya i mediadiskurs: k metodologii issledovaniya. Belgorod State University Scientific bulletin. Philology, Journalism. Pedagogy. Psychology, 12 (83), 6, 13-21. (In Russ).]

Кошкарова Н.Н. «Туманная атака» на чемпионат мира по футболу-2018: британские СМИ о предстоящем спортивном событии // Когнитивные исследования языка. 2018. № 34. C. 706-709. [Koshkarova, N.N. (2018). «Tumannaya ataka» na chempionat mira po futbolu2018: britanskie SMI o predstoyashchem sportivnom sobytii. Cognitive studies of language, 34. (In Russ.)].

Малышева Е.Г. Универсальная идеологема «спорт» в политическом дискурсе СССР и современной России // Личность. Культура. Общество. 2009. Вып. 1. (№ 46-47). С. 330-337. [Malysheva, E.G. (2009). Universalnaya ideologema «sport»v politicheskom diskurse SSSR I sovremennoi Rossii. In Lichnost. Kultura. Obshchestvo, 1 (46-47), 330-337. (In Russ.)]

Малышева Е.Г. Русский спортивный дискурс: лингвокогнитивное исследование. М.: Флинта, 2017. 370 c. [Malysheva, E.G. (2017). Russkii sportivnyi diskurs lingvokognitivnoe issledovanie. Moscow: Flinta. (In Russ.)]

Мартыненко С.Е. Диалектическая взаимосвязь спорта и политики и ее проявление в средствах массовой коммуникации // Вестник МГОУ. История и политические науки. 2014. № 5. C. 179-186. [Martynenko, S.E. (2014). Dialekticheskaya vzaimosvyaz sporta i politiki i ee proyavlenie v sredstvakh massovoi kommunikatsii. Bulletin of the Moscow Region State University. Series: History and Political Sciences, 5, 179-186. (In Russ.)]

Милованова М.В., Свинкина М.Ю. Репрезентация образа России в медиадискурсе Германии в контексте Чемпионата мира по футболу 2018 // Вестник ВолГУ. Серия 2: Языкознание. 2018. T. 17. № 3. C. 148-157. [Milovanova, M.V., Svinkina M.Yu. (2018). Reprezentatsiya obraza Rossii v mediadiskurse Germanii v kontekste Chempionata mira po futbolu 2018. In Bulletin of Volgograd State University, 17 (3), 148-157. (In Russ.)]

Молодов О.Б. Масс-медиа в ракурсе общественного мнения в условиях кризиса // Социальное пространство. 2016. № 2 (4). C. 1-13. [Molodov, O.B. (2016). Massmedia v rakurse 
obshchestvennogo mneniya v usloviyakh krizisa. In Sotsialnoe prostranstvo. 2 (4), 1-13. (In Russ.)]

Нахимова Е.А. Прецедентные феномены как доминанта политического текста // Политическая коммуникаиия: перспективы развития научного направления. УрГПУ. 2014. С. 173-175. [Nakhimova, E.A. (2014). Pretsedentnye fenomeny kak dominanta politicheskogo teksta. In Politicheskaya kommunikatsiya: perspektivy razvitiya nauchnogo napravleniya, 173-175. (In Russ.)]

Новиков Н.В. Политизация франкоязычных спортивных СМИ. Власть политического дискурса // Политическая лингвистика. 2015. № 2 (52). С. 206-213. [Novikov, N.V. (2015). Politizatsiya frankoyazychnykh sportivnykh SMI. Vlast politicheskogo diskursa. Political Linguistics Journal, 2 (52), 206-213. (In Russ.)]

Обидов О.С. Место и роль СМИ в политике // Известия Института философии, политологии и права им. А. Баховаддинова. 2017. № 2. С. 95-97. [Obidov, O.S. (2017). Mesto i rol SMI $\mathrm{v}$ politike. News of the Institute of philosophy, political science and law named after A. Bahovaddinov of the Academy of Science of the Republic of Tajikistan, 2, 95-97. (In Russ.)]

Озюменко В.И. Медийный дискурс в атмосфере информационной войны: от манипуляции к агрессии // Вестник Российского университета дружбы народов. Серия: Лингвистика = Russian Journal of Linguistics. Том 21. № 1. C. 203-220. [Ozyumenko, Vladimir (2017). Media Discourse in an Atmosphere of Information Warfare: From Manipulation to Aggression. Russian Journal of Linguistics, 21 (1), 203-220. (In Russ.)]

Прилукова Е.Г. Власть симулякров // Известия высших учебных заведений. Уральский регион. 2013. № 5. C. 84 -87. [Prilukova, E.G. (2013). Vlast simulyakrov. Izvestiya vysshikh uchebnykh zavedenii. Uralskii region, 5, 84-87. (In Russ.)]

Путин В.В. Гала-концерт в преддверии финала чемпионата мира по футболу. URL: http://kremlin.ru/events/president/news/58001 (дата обращения: 23.07.2018). [Putin, V.V. Galakontsert v preddverii finala chempionata mira po futbolu. http://kremlin.ru/events/ president/news/58001 (In Russ.)]

Пушкарева B.В. Представление о России в журнале “OSTEUROPA”: проблемы толерантности. Обзор публикаций за 2008-2016 г. // Вестник Удмуртского университета. Сочиология. Политология. Международные отночения. 2017. T. 1. № 1. C. 95-102. [Pushkareva, V.V. (2017). Predstavlenie o rossii v zhurnale "Osteuropa": problemy tolerantnosti. Obzor publikatsii za 2008-2016 g. Bulletin of Udmurt University. Socilology. Political Science. International Relations, 1 (1), 95-102 (In Russ.)]

Русакова О.Ф., Корнеева В.А. Спорт как сфера применения «мягкой» и «жесткой» сил политического влияния // Теории и проблемы политических исследований. 2016. Т. 5. № 5А. C. 195-207. [Rusakova, O.F., Korneeva V.A. (2016). Sport kak sfera primeneniya «myagkoi» I «zhestkoi» sil politicheskogo vliyaniya. Teorii i problemy politicheskikh issledovanii, 5 (5A), 195-207 (In Russ.)]

Саражакова А.С. Особенности освещения зарубежными СМИ процесса подготовки к чемпионату мира по футболу 2018 // Проблемы науки. 2018. 7 (31). C. 87-91. [Sarazhakova, A.S. (2018). Osobennosti osveshcheniya zarubezhnymi SMI protsessa podgotovki k chemipionatu mira po futbolu 2018. Problems of Science. 7(31), 87-91. (In Russ.)]

Солопова О.А., Чудинов А.П. Диахронический анализ метафор в британском корпусе текстов: колокола победы и Russia's V-day // Вестник Российского университета дружбы народов. Серия: Лингвистика = Russian Journal of Linguistics. Том 22. № 2. С. 313-337 [Solopova, Olga and Chudinov, Anatoly (2018). Diachronic Analysis of Political Metaphors in the British Corpus: from Victory Bells to Russia's V-Day. Russian Journal of Linguistics, 22 (2), 313-337. doi: 10.22363/2312-9182-2018-22-2-313-337 (In Russ.)] 
Суходолов А.П. Идеологическая функция журналистики // Bопросы теории и практики журналистики. 2014. № 1. С. 11-16. [Sukhodolov, A.P. (2014). Ideologicheskaya funktsiya zhurnalistiki. Theoretical and Practical Issues of Journalism, 1, 11-16. (In Russ.)]

Филонов В.И., Юдина А.В. Политический фактор в сфере большого спорта: теоретико-методологический аспект // Вестник Поволжского института управления. 2018. Т. 18. № 1. C. 106 - 112. [Filonov, V.I., Yudin,a A.V. (2018). Politicheskii faktor v sfere bolshogo sporta teoretiko-metodologicheskii aspekt. The Bulletin of the Volga Region Institute of Administration. 18 (1). 106-112. (In Russ.)]

Чернышева А.Ю. Лингвопрагматика призыва // Филология и культура. 2016. № 2 (44). С. 152158. [Chernysheva, A.Yu. (2016). Lingvopragmatika prizyva. Philology and Culture, 2 (44), 152-158. (In Russ.)].

Шапочкин Д.В. Метод когнитивного анализа дискурса в лингвистике // Вестник Челябинского государственного университета. 2013. № 10 (301). Филология. Искусствоведение. Вып. 76. C. 101-107. [Shapochkin, D.V. (2013). Metod kognitivnogo analiza diskursa v lingvistike. Vestnik Chelyabinskogo gosudarstvennogo universiteta. Filologiya. Iskusstvovedenie, 10 (301), 101-107. (In Russ.)]

Bukowick, Karen Elizabeth (2004). Truth and Symbolism: Mythological Perspectives of the Wolf and Crow. BA, Boston College, http://hdl.handle.net/2345/489.

Horniak, Richard (2016). Influence of Political Parties and the Media on the Formation of Public Opinion. Challenges of the Future, 1 (4), 188-200.

Joffee, Josef (2016). Putinism or Nationalism? Neither. Opportunism. Strategika. Conflicts of the Past as Lessons for the Present, 37, 7-9.

Larina, Tatiana, Vladimir Ozyumenko and Douglas Ponton (2019). Persuasion strategies in media discourse about Russia: Linguistic ambiguity and uncertainty. Lodz Papers in Pragmatics (forthcoming).

Mehraj, Hakim Khalid, Bhat Akhtan Neyaz, Mehraj, Hakeem Rameez (2014). Impacts of Media on Society: a Sociological Perspective. International Journal of Humanities and Social Science Invention, 3 (6), 56-64.

Ponton, Douglas M. and Larina, Tatiana. (2016). Discourse analysis in the 12-st century: Theory and Practice. Russian Journal of Linguistics, 20 (4), 7-25.

Shippi, Panayiotis (2012). Social and Political Factors Affecting Sporting Success in Small Countries: The Case of Cyprus. Biomedical Human Kinetics, 4, 38-44.

Tomi, Leena M. (2001). Critical Analysis of American Representations of Russians. Pragmatics, 11 (3), 263-283.

Thongprayoon, Boonchan, Hill, Brooks L. U.S. Mass Media and Thai Society. Intercultural Communication Studies, 1996, VI: 1, 53-74.

Zirin, Dave (2013). Game Over: How Politics Has Turned the Sports World Upside Down. New York: The New Press.

\section{Article history:}

Received: 27 January 2019

Revised: 14 March 2019

Accepted: 25 March 2019

\section{История статьи:}

Дата поступления в редакцию: 27 января 2019

Дата принятия к печати: 25 марта 2019 


\section{Bionote:}

NATALYA N. KOSHKAROVA, Doctor of Philology, Professor at the Institute of Linguistics and International Communications of South Ural State University (National Research University). Research interests include discursive studies, speech acts theory and political discourse.

Contact information: e-mail: koshkarovann@susu.ru

ORCID: 0000-0001-8861-0353

eLibrary SPIN-код: 3844-0536

\section{Сведения об авторе:}

НАТАЛЬЯ НИКОЛАЕВНА КОШКАРОВА - доктор филологических наук, профессор кафедры международных отношений, политологии и регионоведения института лингвистики и международных коммуникаций, ФГАОУ ВО «Южно-Уральский государственный университет (национальный исследовательский университет)». Сфера научных интересов: дискурсивные исследования, теория речевых жанров, политический дискурс.

Контактная информация: e-mail: koshkarovann@susu.ru

ORCID: 0000-0001-8861-0353

eLibrary SPIN-код: 3844-0536 